\title{
How to foster collaborative learning in communities of teachers and student teachers: Introduction to a special issue
}

\author{
W. Admiraal · S. F. Akkerman • R. de Graaff
}

Received: 23 May 2011/ Accepted: 1 July 2011/Published online: 16 September 2012

(C) Springer Science+Business Media B.V. 2012

Teachers in secondary education mainly feel responsibility for their own classroom practice, resulting in largely autonomous and isolated work and private learning activities. Most teachers teach separate classes behind closed doors and learn about teaching by teaching, which often is described as trial and error (Hodkinson and Hodkinson 2003, 2004). Moreover, teacher professional development mostly takes place outside school, thus removing teacher learning from the workplace (McMahon 1999). Recent educational literature focuses on teachers as professionals working in a particular school culture, being affected and motivated by the way in which they develop and maintain relationships and mutual interests with colleagues. There is particular attention for the way in which teachers can work and learn in what are called teacher communities (Grossman et al. 2001; Hammerness et al. 2005; Little 2002, 2003; Westheimer 1999).

Along with situated learning theories such as those described by Lave and Wenger (1991), many scholars have come to emphasise learning as a dynamic and social participation process (see, for a review, Roth and Lee 2006). Various related terms have been used to indicate the way in which people work and learn in communities, such as communities of practice (Lave and Wenger 1991), learning communities (Brown et al. 1989) and knowledge building communities (Scardamalia and Bereiter 1994). The widespread interest in professional communities indexes a view of learning and knowledge as being integral in social practice (whether captured in collaborative activities, working artefacts, routines, stories or language). This image of learning is increasingly adopted by social scientists (Sfard 1998). Both the organisational and educational fields have started to look for ways to organise or facilitate professional communities as a way to stimulate and facilitate learning (Hildreth and Kimble 2004). In their conceptual framework of how teachers learn, Shulman and Shulman (2004) recognise the importance of communities and work context. In their model of teacher learning, Shulman and Shulman distinguish three interrelated levels of analysis: the individual, communal and policy. At the communal

W. Admiraal ( $\bowtie)$

ICLON, Leiden University, Leiden, The Netherlands

e-mail: w.f.admiraal@iclon.leidenuniv.nl

S. F. Akkerman · R. de Graaff

Utrecht University, Utrecht, The Netherlands 
level, more specifically, teacher communities are represented with shared visions, community commitments, a shared knowledge base, a community of practice and established rituals or ceremonies for joint reflection and review that serve the development of community accomplishments. The concept of professional communities might not only support teacher learning in schools, but instructional designs of initial teacher education programmes might apply the concept as well.

This special issue aims to contribute to the existing body of literature on teacher communities by questioning the way in which various types of teacher communities throughout the career can be enhanced in their development and the way in which this development can be conceptually framed. Before describing the specific contributions in this special issue, the next section considers how communities of teachers and student teachers are considered to be valuable learning environments.

\section{Value of teacher communities}

Teacher communities are claimed to contribute to improvements in the practices of teaching and schooling (Darling-Hammond and Bransford 2005; Little 2003; Witziers, Sleegers and Imants 1999), as well as to individual teacher development and the collective capacity of schools (Achinstein 2002; Grossman et al. 2001; Imants et al. 2001; Piazza et al. 2009; Seashore Louis et al. 1996). These authors claim that conditions for improving teaching and learning are strengthened when teachers collectively examine less effective teaching practices, study new conceptions of teaching and learning, and support one another's professional growth. Moreover, collaboration within teacher communities is a way to counter isolation, improve teacher practice and create a shared vision towards schooling (Achinstein 2002; Hodkinson and Hodkinson 2003). These studies of teacher communities not only indicate an account of the impact of social environments on learning and working processes, but they also indicate a search for tracing potential communities and an intention to deliberately enhance the development of teacher communities. This intention indicates the potential value of teacher communities for both learning and work. There are several arguments for this perceived potential of teacher communities.

First, teacher communities are valuable environments as they represent a professional culture. Teacher communities are practices emerging from the shared interests of their members, as well as representing the way in which professional norms and values are understood and acted upon by teachers.

Second, communities refer to self-governing and developmental environments. They are self-governing in the sense that:

They typically solve problems, discuss insights, share information, talk about their lives, and ambitions, mentor and coach each other, make plans for community activities, develop tools and frameworks that become part of the common knowledge of the community. Over time these mutual interactions and relationships build up a shared body of knowledge and a sense of identity. (Wenger, 1999, p. 4)

It has been shown how such cohesive groups are able to critically deal with the political, social and economic conditions in which they exist (Cole and Engeström 1993), potentially leading to competitive ideas and creative inventions (Riel and Polin 2004). Hence, teacher communities are learning environments by nature.

Third, teacher communities have specific value in different phases of the teaching career. The learning process of student teachers during teacher education programmes is 
not only about knowing how to teach, but also about becoming a teacher (Akkerman and Meijer 2010; Kelchtermans and Hamilton 2004). Meijer and Oolbekkink-Marchand (2009) showed how collective reflection can help student teachers to determine their own position and responsibilities in teaching. This suggests ways in which student teacher communities can be an effective vehicle for discussing and reflecting on the professional domain and the personal process of becoming a teacher. So, in addition to being a learning environment in teacher education programmes, student-teacher communities can prepare student teachers for their participation in teacher communities in their future professional live.

For beginning teachers, teacher communities can be a way to relate what has been learned in the teacher education institute to what is encountered in work. Recent studies of the context of teacher education consistently confirm insights about how difficult it is for beginning teachers to see the linkages between what is learned at the institute and what is encountered at work (Alsup 2006; Edwards and Mutton 2007; Finlay 2008; Tsui and Law 2007; Yoon et al. 2006). As Edwards and Mutton (2007) have pointed out, work places such as schools often expect those who enter their system to work on their terms. The gap between the training and work contexts is obviously more profound when the institute and students' work environment have different norms and values regarding, for example, pedagogy, collaboration or professional performance (such as team work). Gorodetsky and Barak (2008) show how the emergence of a community of student teachers, school teachers and teacher educators can be a successful form of boundary crossing for student teachers and, at the same time, allow school teachers to develop their own teaching practices.

Also, for expert teachers in school, teacher communities seem to be valuable because they offer a natural way for learning at the work place. Kwakman (1999) found that teachers themselves experience collaboration as an important source of learning. Several studies confirmed the benefits of teacher collaboration for professional development (e.g., Meirink 2007; Shank 2006). Specifically, positive effects have been found for teachers discussing their experiences in the classroom with colleagues, talking about their ideas about good education, and observing each other's lessons, as this leads to self-confidence and enthusiasm of teachers to continue experimenting with new pedagogical approaches in their classrooms (Zwart 2007).

In line with these promising notes on teacher communities, policy documents of teacher education programmes and schools have started referring to the value of teacher communities for stimulating work and learning. Nonetheless, reality seems to lag behind the intentions. Dobber (2011), in a study of three large teacher education programmes in the Netherlands, found how collaboration between student teachers is stimulated by teacher educators and in the curriculum. However, looking at the way in which the curriculum has been realised, there was no explicit or systemic attention (e.g., in terms of organization, reflection or assessment) for the way in which student teachers (learn to) collaborate. Also, in secondary schools in the Netherlands, Bakkenes et al. (2010) found that many, mainlyindividual learning strategies were employed by experienced teachers in their daily work. These results are in line with less recent work suggesting that teachers' professional development mostly takes place outside school, thus removing teacher learning from the workplace (McMahon 1999). These findings indicate that - at least in the Netherlandsteachers learning and working in communities are not common practice yet.

In summary, although it might be a valuable way to learn and work together, making use of communities of teachers and student teachers is not common practice. This brings us to the question of how teacher communities can be organised and continued. In a way, the idea of deliberately designing communities seems to be contradictory to their informal, self-governing nature, a paradox that has been discussed more by Akkerman et al. (2008). 
Wenger et al. (2002) have argued that designing communities is more about cultivating rather than creating communities as such. Accordingly, the idea of this special issue is to take the notion of community as a perspective for looking at existing groups or relationships between (student) teachers and as a perspective for thinking about facilitation and further development. More specifically, the articles in this special issue concentrate on:

- What kind of interventions can be undertaken to facilitate groups in the light of a community perspective in various teacher learning and working environments?

- How can a teacher community be conceptualised and measured in terms of its definition, features, indicators and formation?

The following section summarises how the individual contributions address these questions.

\section{Contributions}

This special issue includes three empirical articles and one framing article on the design of teacher communities in three different types of context. In the article of Dobber, Akkerman, Verloop, Admiraal and Vermunt (this issue), design principles are worked out and evaluated for an optimal arrangement of collaboration within four types of student groups (mentor group, subject-matter group, reflection group, and research group) that vary in the learning aim and the activities that their members perform. Based on qualitative analyses of data from focus groups and meeting with both student teachers and teacher educators, 26 design principles, clustered into three dimensions of teacher communities, are related to the way in which they are realised in the four types of student groups. The authors identify different sets of design principles for different groups, which means that taking a community perspective does not necessarily imply one single solution to be applied in all groups. A tailor-made approach is needed, which is customised in terms of objectives, activities, conditions, tools, context and participants.

In the second article, Vandyck, De Graaff, Pilot and Beishuizen (this issue) report the development, implementation and evaluation of design principles for stimulating community development in school-university partnerships (SUPs) involving teachers, student teachers and teacher educators. The study focuses on the collaboration process for a team of modern language (student) teachers who work and learn together in a teacher community. Based on the cooperative learning model of Johnson and Johnson (1999), 14 design principles are set up, implemented and evaluated. Data on community development are gathered by observations of group meetings and considering 17 clips of $10 \mathrm{~min}$. The feasibility and the effectiveness of these principles are discussed in relation to the specific heterogeneous characteristics of a SUP-team, including status differences between student teachers, experienced teachers and teacher educators.

In the third article, Brouwer, Brekelmans, Nieuwenhuis and Simons (this issue), design principles are set up for a teacher community in secondary schools. Based on a literature review, a list of 24 design principles is retrieved for teacher communities in secondary schools. From this list, eight principles are applied to characterize a team of school teachers who are perceived as the most collaborative in the particular school. These eight design principles are related to interventions, mechanisms by which the intervention works, and outcomes.

Finally, in the fourth article by Admiraal, Lockhorst and Van der Pol (this issue), an expert study is reported in which experts—both practitioners and researchers-discussed the definition, features, indicators and formation of teacher communities in Dutch 
secondary education. A model of teacher community is developed, evaluated and re-designed; this model can be used as a framework for empirical research in the field.

The professional development of teachers in secondary education can take a variety of shapes: collective or individual development, continuing education, preservice and inservice education, etc. In each, community building can be a significant feature of the professional development of teachers. According to Shulman and Shulman (2004), an accomplished teacher "is a member of a professional community who is ready, willing, and able to teach and to learn his or her teaching experience" (pp. 259). The interventions and conceptual framework of teacher communities suggested in the articles in this special issue might be promising tools for supporting the professional development of teachers.

\section{References}

Achinstein, B. (2002). Conflict amid community: The micropolitics of teacher collaboration. Teachers College Record, 104, 421-455.

Akkerman, S. F., \& Meijer, P. (2010). A dialogical approach to conceptualize teachers' identity. Teaching and Teacher Education., 27, 308-319.

Akkerman, S., Petter, C., \& de Laat, M. (2008). Organizing communities-of-practice: Facilitating emergence. Journal of Workplace Learning, 6, 383-399.

Alsup, J. (2006). Teacher identity discourses: Negotiating personal and professional spaces. New Jersey: Lawrence Erlbaum Associates, Inc.

Bakkenes, I., Vermunt, J. D., \& Wubbels, T. (2010). Teacher learning in the context of educational innovation: Learning activities and learning outcomes of experienced teachers. Learning and Instruction, 20, 533-548.

Brown, J. L., Collins, A., \& Duguid, P. (1989). Situated cognition and the culture of learning. Educational Researcher, 18(1), 32-42.

Cole, M., \& Engeström, Y. (1993). A cultural-historical approach to districbuted cognition. In G. Salomon (Ed.), Distributed cognition (pp. 1-46). Cambridge: Cambridge University Press.

Darling-Hammond, L., \& Bransford, J. (Eds.). (2005). Preparing teachers for a changing world: What teachers should learn and be able to do. San Francisco: Jossye-Bass.

Dobber, M. (2011). Collaboration in groups during teacher education. Doctoral dissertation, Leiden University, the Netherlands.

Edwards, A., \& Mutton, T. (2007). Looking forward: Rethinking professional learning through partnership arrangements in initial teacher education. Oxford Review of Education, 33, 503-519.

Finlay, I. (2008). Learning through boundary-crossing: Further education lecturers learning in both the university and workplace. European Journal of Teacher Education, 31, 73-87.

Gorodetsky, M., \& Barak, J. (2008). The educational-cultural edge: A participative learning environment for co-emergence of personal and institutional growth. Teaching and Teacher Education, 24, 1907-1918.

Grossman, P., Wineburg, S., \& Woolworth, S. (2001). Toward a theory of teacher community. Teachers College Record, 103, 942-1012.

Hammerness, K., Darling-Hammond, L., Bransford, J., Berliner, D., Cochran-Smith, M., McDonald, M., et al. (2005). How teachers learn and develop. In L. Darling-Hammond \& J. Bransford (Eds.), Preparing teachers for a changing world (pp. 358-389). San Francisco: Jossey-Bass.

Hildreth, P., \& Kimble, C. (2004). Knowledge networks: Innovation through communities of practice. London: Idea Group Publishing.

Hodkinson, P., \& Hodkinson, H. (2003). Individuals, communities of practice and the policy context: School teachers' learning in their workplace. Studies in Continuing Education, 25, 3-21.

Hodkinson, H., \& Hodkinson, P. (2004). Rethinking the concept of communities of practice in relation to schoolteachers' workplace learning. International Journal of Training and Development, 8, 21-31.

Imants, J., Sleegers, P., \& Witziers, B. (2001). The tension between sub-structures in secondary schools and educational reform. School Leadership \& Management, 21, 289-308.

Johnson, D. W., \& Johnson, R. T. (1999). Learning together and alone: Cooperative, competitive, and individualistic learning (5th ed.). Boston, MA: Allyn \& Bacon. 
Kelchtermans, G., \& Hamilton, M. L. (2004). The dialectics of passion and theory: Exploring the relationship between self-study and emotion. In J. J. Loughran, M. L. Hamilton, V. Kubler LaBoskey, \& T. Russell (Eds.), International handbook of self-study of teaching and teacher education practices (pp. 785-810). Dordrecht, the Netherlands: Kluwer Academic Publishers.

Kwakman, C. H. E. (1999). Leren van docenten tijdens de beroepsloopbaan. Studies naar professionaliteit op de werkplek in het voortgezet onderwijs. Doctoral dissertation, Radboud University, Nijmegen, the Netherlands.

Lave, J., \& Wenger, E. (1991). Situated learning: Legitimate peripheral participation. Cambridge: Cambridge University Press.

Little, J. W. (2002). Locating learning in teachers' communities of practice: Opening up problems of analysis in records of everyday work. Teaching and Teacher Education, 18, 917-946.

Little, J. W. (2003). Professional community and the problem of high school reform. International Journal of Educational Research, 37, 693-714.

McMahon, A. (1999). Promoting continuing professional development for teachers: An achievable target for school leaders? In T. Busch, L. Bell, R. Bolam, R. Glatter, \& P. Ribbins (Eds.), Educational management: Redefining theory, policy and practice (pp. 102-113). London: Paul Chapman Publishing.

Meijer, P. C., \& Oolbekkink-Marchand, H. (2009). Tracing learning in collaborative reflection meetings of student teachers. In C. J. Craig \& L. F. Deretchin (Eds.), Teacher learning in small-group settings (Teacher Education Yearbook XVII, pp.178-199). Lanham, MD: Rowman \& Littlefield.

Meirink, J. A. (2007). Individual teacher learning in a context of collaboration in teams. Doctoral dissertation, Leiden University, the Netherlands.

Piazza, P., McNeill, K. L., \& Hittinger, J. (2009, April). Developing a voluntary teacher community: The role of professional development, collaborative learning and conflict. Paper presented at the annual meeting of the American Educational Research Association, San Diego, CA.

Riel, M., \& Polin, L. (2004). Online learning communities: Common ground and critical differences in designing technical environments. In S. A. Barab, R. Kling, \& J. Gray (Eds.), Designing for virtual communities in the service of learning (pp. 16-52). Cambridge, MA: Cambridge University Press.

Roth, W.-M., \& Lee, Y.-J. (2006). Contradictions in theorizing and implementing communities in education. Educational Research Review, 1, 27-40.

Scardamalia, M., \& Bereiter, C. (1994). Computer support for knowledge building communities. Journal of the Learning Sciences, 3, 265-283.

Seashore Louis, K., Marks, H., \& Kruse, S. (1996). Teachers' professional community in restructuring schools. American Educational Research Journal, 33, 757-798.

Sfard, A. (1998). On two metaphors for learning and the danger of choosing just one. Educational Researcher, 27, 4-13.

Shank, M. J. (2006). Teacher storytelling: A means for creating and learning within a collaborative space. Teaching and Teacher Education, 22, 711-721.

Shulman, L. S., \& Shulman, J. H. (2004). How and what teachers learn: A shifting perspective. Journal of Curriculum Studies, 36, 257-271.

Tsui, A. B. M., \& Law, D. Y. K. (2007). Learning as boundary-crossing in school-university partnership. Teaching and Teacher Education, 23, 1289-1301.

Wenger, E. (1999). Learning as a social system. Systems thinker, 9(5), 2-3.

Wenger, E., McDermott, R., \& Snyder, W. (2002). Cultivating communities of practice. Boston: Harvard Business School Press.

Westheimer, J. (1999). Communities and consequences: An inquiry into ideology and practice in teachers' professional work. Educational Administration Quarterly, 35, 71-105.

Witziers, B., Sleegers, P., \& Imants, J. (1999). Departments as teams: Functioning, variations and alternatives. School Leadership \& Management, 19, 293-304.

Yoon, S., Pedretti, E., Bencze, L., Hewitt, J., Perris, K., \& Van Oostveen, R. (2006). Exploring the use of cases and case methods in influencing elementary preservice science teachers' self-efficacy beliefs. Journal of Science Teacher Education, 17, 15-35.

Zwart, R. C. (2007). Teacher learning in a context of reciprocal peer coaching. Doctoral dissertation, Radboud University, Nijmegen, the Netherlands. 